\title{
Shaping students' identity through EFL in Belgrade high schools
}

\author{
Tamara P. Tošić*
}

University of Belgrade, Faculty of Philology

\section{Key words:}

language and identity

English language

teaching

Belgrade high schools

world Englishes

instrumental

motivation

integrative motivation

\section{Abstract}

The global spread of English has led to a myriad of speculations as to whether the language affects learners' identities and, if so, whether the consequences are positive or negative. Thus, the two hypotheses leading this paper assert that the Serbian element of Belgrade high school students' networks of identities is unshaken, but that their English teachers have a central role in shaping their identities. The data was compiled using two research methods - a questionnaire completed by the students and an interview done with their English teachers. The study incorporated 158 third- and fourth-grade students from the Sixth and Fifth Belgrade High School and three teachers. The analysis of the responses confirms the hypotheses, with special emphasis on the fact that the teachers are responsible for the formation of the students' identities. However, the data also reveals the existence of a small but distinct and vociferous minority of students who identify themselves with the English speech community. Therefore, not only should ELT practitioners in Serbia work on developing the learners' critical thinking skills and introducing world Englishes into the classroom, but they should also attune their approach to students with both instrumental and integrative motivation. (примюено: 21. августа 2021; прихваћено: 15. септембра 2021) 


\section{Theoretical framework}

\subsection{Language and identity}

Identity is a multi-faceted concept whose numerous features have been extensively investigated by scholars across various disciplines. Thus, there is a great number of accepted definitions taking different approaches to the term. The most comprehensive one is offered by Tabouret-Keller (1998): "[...] identity is rather a network of identities, reflecting the many commitments, allegiances, loyalties, passions, and hatreds everyone tries to handle in ever-varying compromise strategies". This definition points to the many aspects our identities have. Firstly, identity is not a monolithic phenomenon; it is, as Tabouret-Keller states, actually a network of different identities. Furthermore, the definition highlights the conscious aspect of identities - commitments, allegiances, loyalties, passions and hatreds all imply that identities are shaped through people's deliberate actions. Moreover, the word ever-varying points to the fact that identities are dynamic; they are not set in stone, but prone to change. Finally, from phrases such as allegiances, loyalties and compromise strategies it can be inferred that two groups are at play when identities are being formed - us and them - and we choose which group will be us and which one will be them. The us vs. them aspect of identity is emphasized by Bugarski (2010: 12), using two different words - selfsameness and otherness - which also accurately portray how identities work. Bastardas-Boada (2012: 20) elaborates on that point: "It is in such situations, typically characterised by the contact between a majority group and one - or more - minorities, in which we usually see the emergence of the individual and at the same time the collective phenomenon known as 'identity". Therefore, we can conclude that identity consists of a network of dynamic elements, which result from conscious decisions made so as to distinguish us from them.

Having defined the concept of identity, we will continue by classifying different types of identities for the sake of pinpointing the identity type which is the subject of this paper. Blommaert (2006: 238) differentiates between achieved or inhabited identity and ascribed or attributed identity. The main focus of the research is the students' achieved identity - the place they decided to devote to English in their identity networks. Nevertheless, the research hinges on the students' ascribed identity, since some of their national identities, which are also examined in this study, may be ascribed. Bugarski (2011: 12) defines levels and layers of identity, among other divisions. The levels of identity that exist, according to Bugarski (2011: 13), are identity as humanity, identity as collectivity and identity as individuality. This paper mainly deals with identity on an individual level, but it aims to make conclusions which will be valid for the second, collective level. The layers Bugarski (2011: 13) recognizes are ethnic, national, religious, linguistic, cultural, territorial, generational, gender-related, professional, political, etc. The focal point of the research will be the students' linguistic, national and, partly, cultural identities. Thus, in brief, this paper mainly deals with Belgrade high school students' individual achieved linguistic, national and cultural identities, with a view to extrapolating the data to the collective level. 
Since the relationship between language and identity is the main thread running through the theoretical framework of this paper, the remainder of this section will be dedicated to that topic. Tabouret-Keller (1998) stresses that language has a twofold function in identification - it is an external factor whose existence enables its speakers to see themselves as belonging to a particular speech community, but it is also a tool its speakers use to identify themselves. The second function is also emphasized by Edwards (2009: 21), who says language is an identity marker. In fact, the said function is one of the most significant relations which can be drawn between language and identity. Dyer (2007: 102) terms it indexicality and offers a definition: "The process by which language comes to be associated with specific locally or contextually significant social characteristics is referred to as the indexicality of language [...]". Coupland (2007: 22) gives a similar definition of the term and expands it by citing Pierce's explanation of the term index, quite Saussurean in essence - it represents the link between the sign and the referent. Thus, indexicality is realized in speech when the speaker uses an index during a conversation, regardless of whether the hearer manages to interpret the index or not. For instance, if a speaker intentionally and consistently uses English loanwords (i.e. anglicisms) in place of their already existing Serbian equivalents, the index is the speaker's aim to stress his/her belonging to the English speech community. Whether the hearer is able to interpret the index or not is insignificant because the speaker establishes the us vs. them distinction independently of the hearer. In a similar vein, an individual avoiding anglicisms at all costs is using indexicality with the aim of distancing himself/herself from the English speech community.

Indexicality and the stated example are closely related to acts of identity. Coupland (2007: 109) elucidates acts of identity by quoting Le Page and TabouretKeller: "[T]he individual creates for himself the patterns of his linguistic behaviour so as to resemble those of the group or groups with which from time to time he wishes to be identified, or so as to be unlike those from whom he wishes to be distinguished". In a similar vein, Edwards (2009: 32) presents the speech accommodation theory, the gist of which is that speakers tend to adjust the manner in which they speak to standards they deem socially desirable. To instantiate the two phenomena, they will be applied to EFL students in Serbia. For example, should Serbian EFL speakers desire to approach the English speech community, they will expend considerable effort to make their English sound as similar as possible to the English spoken by native speakers. Vice versa, they will deliberately employ a non-native, Serbian accent while speaking English if they want to highlight the Serbian element of their identity networks.

Bilinguals' identities are particularly interesting for the matter at hand since the vast majority of Belgrade high school students can be considered bilingual (in Serbian and English) to an extent. Edwards (2009: 54) mentions instrumental bilingualism and characterizes it as "pragmatically driven bilingualism". People who are instrumentally bilingual speak one language which they use for noninstrumental purposes and identify with more, while they use the other language 
with instrumental motivation only. They incorporate the "instrumental" language in their identities as a tool for communication. This is the case with many people in Serbia, and, perhaps, with Belgrade high school students as well, which will be investigated in the empirical part of this paper. Furthermore, Edwards (2009: 249) claims that bilinguals may draw on different aspects of their personalities when speaking two different languages. For instance, a completely bilingual person who speaks Serbian and English might express attitudes in Serbian which are dissimilar from those he/she voices in English. When studying Belgrade high school students, the fact that they do not convey identical opinions in both Serbian and English can point to a higher level of bilingualism and, hence, to a more prominent position held by English in their identity networks.

Another connection between language and identity can be found in the attitudes that the speakers express. As Bugarski (2010: 31) states while discussing Serbo-Croatian identity, it is "mostly an issue of attitude - not as much to the language variations themselves as to the relations among the national groups using the language". ${ }^{1}$ Edwards (2009: 57) also foregrounds the notion that the attitudes speakers air towards other languages are, in fact, their opinions on the speech communities using those languages. Thus, attitudes are another tool speakers employ to weave their identity webs, which means they can be used to analyze those webs. For instance, speakers asserting they like the English language is tantamount to them conveying positive emotions towards the English speech community, which signifies that they are prone to incorporating English into their identity networks. Negative attitudes towards the speakers' native speech community are of particular significance since, according to Bastardas-Boada (2012: 111), English can pose a threat to other speech communities only if a negative attitude towards their own community arises among the speakers of those languages. If extrapolated to the individual level, this claim would amount to subtractive bilingualism, which places the language being learnt at an advantage in the speaker's identity, while the language he/she originally spoke is disadvantaged.

To conclude this section, we turn to a language policy document issued by the European Commission, called A Rewarding Challenge. In it, languages are seen as having the possibility of taking up three possible positions in the speakers' identity networks - the language of identity, the personal adoptive language and the language of international communication (European Commission, 2008: 7). The language of identity is most commonly the speaker's native language, the language of international communication is the language the speaker decides to learn for the sake of communicating abroad, and the personal adoptive language is selected on the basis of personal reasons only, whatever they may be (European Commission, 2008: 7). This categorization is particularly useful for the issue at hand. Therefore, one of the aims of this paper will be to determine which of these categories are occupied by English in Belgrade high school students' identity networks.

1 Serb. “dobrim delom pitanje stava - ne toliko prema samim jezičkim varijacijama koliko prema odnosima među nacionalnim grupacijama koje se tim jezikom služe” 


\subsection{Global English(es)}

The English language has taken the world by storm. Its spread is so unprecedented that it demands the creation of new classifications and scientific perspectives. One of those perspectives, which explains the current position of English in the world highly accurately, is provided by Kachru. He notices that there are three concentric circles of English speakers - the Inner Circle, the Outer Circle and the Expanding Circle (presented in Crystal, 2003: 60-61). The Inner Circle consists of the countries where English is spoken as a native language (e.g. the USA, the UK, Australia, etc.), the Outer Circle is made up of countries where English is a second or official language (e.g. India, South Africa, Singapore, etc.) and the Expanding Circle (or, as Crystal terms it, Expanded Circle) encompasses countries where English is learned as a foreign language and spoken as an international language (e.g. Serbia, Germany, Greece, etc.) (Crystal, 2003: 60-61). Based on these circles, Crystal (2003: 144) stresses the existence of not one English but numerous Englishes, starting with the Inner Circle varieties and moving on to the Outer and even Expanding Circle varieties - New Englishes. Both of these insights intentionally move the focus from the Inner Circle countries to the Outer and Expanding Circle countries. English is now being used in Europe, Asia and Africa as frequently as in the Inner Circle or, arguably, more frequently.

Of particular significance for this paper is the position English holds in Europe, which will be elaborated on below. English became a staple subject in continental European schools after World War II, substituting languages such as French and German, which had been given primacy before the war (Modiano, 2006: 223-224). Ever since mainland Europeans started learning English, the dominant variety for them has been British English, owing to the fact that virtually all official teaching materials used in Europe come from Britain, with the British Council taking on a major role in European ELT (Modiano, 2006: 223). Thus, as Modiano (2006: 225, 227) states and my own experience as an English learner from Serbia confirms, English teachers in Europe are mostly Anglocentric and reluctant to abandon the Standard British variety. A study conducted by Grubor, Hinić and Petrović-Desnica (2011) validates this claim. By analyzing the data gathered during the study, which included 92 non-native English teachers from 25 European and 18 non-European countries, the researchers came to the conclusion that a substantial majority of teachers prefer the British variant of English, which reaffirms "the dominance of $\mathrm{BrE}$ in the field of education" (Grubor et al., 2011: 454).

On the other hand, the discrepancy between the English the students learn at school and the variety they are exposed to through the media is striking. Namely, as Modiano (2006: 225) says, a sizeable portion of English that Europeans come across in the media is American English. Proof that the media affects the English spoken by people from the former Yugoslavia region can be obtained from a study carried out by Mihaljević Djigunović, Cergol and Li (2006). Namely, their research included 63 individuals who had not had the opportunity to learn English during their formal education and confirmed that incidental vocabulary acquisition occurs through the 
agency of the media (Mihaljević Djigunović et al., 2006: 447, 451). In Serbia, Čorbić (2011: 402) notices that double acquisition takes place among English students at the University of Belgrade - they acquire English simultaneously in formal and informal contexts. Therefore, EFL students find themselves in a rift between the American English they hear in the media, and perhaps use on social media, and the British English they are supposed to learn and produce at school. This leads to the creation of what Modiano terms Euro-English, or even Euro-Englishes. He sees EuroEnglish as a combination of the British taught at European schools, the American heard in the media and the inevitable L1 interference (Modiano, 2006: 231). Bearing that in mind, we can conclude that students of all ages in Serbia, myself included, as well as people all around Europe are taking part in the creation of a new variety of English - Euro-English.

All of these changes, brought about by the unparalleled spread of English, have been met with a wide spectrum of responses from the general and scientific public. Whereas some believe that the spread of English is a mere continuation of past imperialistic tendencies (see Phillipson 2000; Phillipson 2001), others equate it with the spread of Latin which "spawned a renewed heterogeneity" (Edwards, 2009: 238). When considering the range of attitudes spanning from linguistic imperialism to English globalism, I believe that there is no denying that English is still in the ownership of its native speakers, but the situation is not as terrifying as some of the prophets of doom and gloom portray it. In my opinion, Kachru painted the best picture of English as a global language - the natives are still in the center (the Inner Circle), but the Outer and, especially, Expanding Circles are getting larger and larger, with an ever-growing number of non-native speakers and the varieties they create. Nonetheless, I think that a near-imperialistic situation can occur in the ELT classroom. As Modiano (2001: 339-340) states, two beliefs ELT practitioners are prone to expressing can affect the students' identities - insisting on a specific variety of English and insisting on near-native proficiency. When an English teacher strongly prefers one English variant, students who desire to speak another variant may feel neglected (Modiano, 2001: 340). Moreover, such an attitude may establish English as belonging only to one portion of the English-speaking population Britons, Americans, Australians, etc. (Modiano, 2001: 340). If the teachers insist on achieving near-native proficiency in English, the students who do not desire to integrate themselves into the natives' speech communities may feel like "auxiliary members of the culture which is represented by the prescriptive educational standard, something not in harmony with their own self-image" (Modiano, 2001: 340). Heavy emphasis must be placed on the conclusion that both of these attitudes that teachers tend to voice directly affect the formation of the learners' identities and the way they see themselves.

\section{Aim and hypotheses}

Modiano's ideas provide a great segue into the aim and hypotheses of this paper. As was previously stated, the variety dominant in ELT in Serbia is British English, 
which allows us to infer that a certain portion of Serbian ELT practitioners take the two mentioned near-imperialistic stances regarding the standard of English being taught. Consequently, the practitioners may be shaping the students' networks of identities, willingly or unwillingly. Thus, this research aims to determine the extent to which ELT teachers in Serbia, with their practices and convictions, participate in the formation of their students' identity webs. Two hypotheses will be examined in order to achieve the said aim: (1) the Serbian element is unshaken in Belgrade high school students' identity networks, while English assumes the role of an international language, used as an instrument of communication; (2) teachers' attitudes influence their students profoundly, especially those students who are awarded the best grades. The hypotheses are based on the theoretical framework described above and a pilot study conducted prior to the writing of this paper. ${ }^{2}$

\section{Research methods}

Two methods were employed in order to confirm or disprove the hypotheses stated in 2. - a questionnaire and an interview. ${ }^{3}$ The questionnaire, intended for the students, was created using the free online software Google Forms. It was formulated in Serbian in order to avoid potential misunderstandings caused by vocabulary unfamiliar to the students. The part which required the teachers' participation was the interview. All interviews were conducted using an online video communication platform, either Zoom or Google Meet. Similarly to the survey, the interviews were carried out in Serbian in an attempt to allow the teachers to focus solely on their attitudes, without having to think about the language they use to express themselves. The teachers also distributed the questionnaires to the students using the Google Classroom service. The research was entirely carried out online since the current COVID-19 pandemic made it difficult to access schools and classrooms live.

The principal parameter taken into consideration while devising the sample was age. In order to probe into the issues central to the two hypotheses of this paper most adequately, only students of the third and fourth grade of high school were included in the research. The reasons for this decision were twofold. Firstly, third- and fourth-graders, who were seventeen to nineteen years old at the time, had already been highly exposed to the English language, as well as to a myriad of different attitudes towards its current position in the world. Most certainly, all of that had contributed substantially to the formation of their identities as regards English, which the study aimed to examine. Secondly, they had had English classes with their respective teachers for at least two years; thus, they had been in

2 The pilot study was an intrinsic case study carried out for a shorter paper written as a part of the exam pre-requisites for Special Topics in Sociolinguistics, a course I took during my master's degree program. Three third-grade classes of students (i.e. 51 students) from the Sixth Belgrade High School and their teacher participated in the pilot study.

3 I would like to express my gratitude to Professor Jelena Filipović from the Department of Iberian Studies at the Faculty of Philology, University of Belgrade, who taught the Special Topics in Sociolinguistics course and suggested that I incorporate an interview with the teachers into my study along with the questionnaire. 
prolonged contact with the teachers and, most probably, had been acquainted with their beliefs and attitudes.

The sample encompassed seven classes from two different schools and their teachers - three fourth-grade classes from the Sixth Belgrade High School, two third-grade classes from the Fifth Belgrade High School and two fourth-grade classes also from the Fifth Belgrade High School. The decision to incorporate students from the Fifth High School was made owing to the fact that the students share socio-economic characteristics with their peers from the Sixth High School. Unlike the Sixth High School, only two classes per grade were taken from the Fifth High School since teachers are assigned to teach fewer classes in that school. The online survey was distributed to the fourth-graders from the Sixth High School on 5/4/2020, which was also when the interview with their teacher was conducted. The number of students in the three classes amounts to 87, but 62 of them chose to fill in the questionnaire as of 16/5/2020. The research in the Fifth High School was conducted approximately two weeks later. The interviews with both of the teachers took place on 29/4/2020, while the third-graders and fourth-graders received the questionnaire on $22 / 4 / 2020$ and $20 / 4 / 2020$, respectively. The aggregate number of students in the four classes is 120,96 of which responded to the survey through $16 / 5 / 2020$. Therefore, the total number of participants in the study is 158 students and 3 teachers.

With reference to the limitations of this paper, the first one is related to the fact that participation in the survey was completely voluntary, which may skew the results. Namely, it is probable that only the students who find the topic interesting filled out the questionnaire, while those who are less compelled to discuss their relationship with English decided not to respond. Furthermore, the results gathered from the data analysis can only be applied to the population of Belgrade high school students. Further research into the identities of students of vocational high schools in Belgrade should be carried out so that the results can be deemed relevant to all high school students in Belgrade. Likewise, were there a desire to broaden the scope of the research to encompass all high school students in Serbia, students from other towns and cities could be included.

\section{Discussion and analysis}

The research results will first be presented separately - the discussion and analysis of the questionnaire results will be covered first, followed by a concise presentation of the teachers' responses to the interview questions. Having displayed and analyzed all the findings gathered by employing the two main methods of research, the data will be synthesized by drawing conclusions from the potential correlation between the students' and the teachers' answers.

\subsection{Discussion and analysis of questionnaire findings}

The questionnaire comprised 16 questions, which will first be analyzed individually. Having stated those results, a demographic factor - the students' final grades - will be taken into consideration with a view to examining the probable 
interrelationship between the grades and the students' identities. The attempt at discovering a correlation will be made by separately studying the answers given by respondents with the highest and lowest final grades.

One of the opening questions in the questionnaire, inquiring about the respondents' birth country, was "eliminatory". It showed that three students had been born in countries outside of the former Yugoslavia area. Namely, their birth countries were Hungary, the United Arab Emirates and Cuba. The reason for omitting their answers from the overall analysis is the possibility that they went to an international elementary school in their countries of birth and, thus, could have been educated in English. This would render their networks of identities markedly different from the ones of their peers who were born and raised in Serbia. Moreover, 10 more responses were eliminated since they were duplicates of other responses, i.e. they had the exact same answers. Even the answers to open-ended questions were worded in the same manner. Hence, the final number of participants in the research was reduced from 158 to 145, which will be considered in depth below.

As anticipated, the students' preferences regarding varieties of English are split between the two most widespread ones - the American and the British variety. The majority of the students choose American English as the most desirable variety of English - 86 of them to be exact, which makes up 59.3 percent of the sample, while the British variety holds a smaller portion of the answers -47 responses in total, which accounts for 32.4 percent. The remaining 8.3 percent of the participants consider other varieties of English to be the best. Namely, 6 respondents select Canadian English (4.1 percent), 3 of them like Australian English (2.1 percent), 2 opt for New Zealand English (1.4 percent), while one participant used the "Other" option to express his/her inclination towards a non-native, Russian variety of English. While these results do assert the dominance of the American variant of English, they also show that many students display awareness of and preference for the less popular variants.

When it comes to the conscious decisions the students make when speaking English, precisely two thirds of the participants desire to sound as similar as possible to speakers whose mother tongue is English, as can be seen in Figure 1. Unlike them, 7.6 percent of their fellow students strive to come across as Serbian speakers of English, while 25.5 percent of them put no particular effort into their accent when speaking English. These findings signal that a substantial majority of students wish to appear as if they belonged to the native English speech community, whereas a small yet distinct minority makes a conscious decision to speak English with a non-native, Serbian accent. The latter group utilizes the indexicality of the non-native accent to emphasize their identities as members of the Serbian speech community. Nonetheless, the data collected in relation to the former group does not necessarily imply that all of them have a tendency to give English a prominent role in their networks of identities. That is to say, native-sounding English is still perceived as the standard in Serbia; thus, the students might, for instance, be given 
a lower grade if they display non-native features in their speech. Therefore, their answers are, most probably, a necessity, not a choice.

Effort to sound like Serbian speakers of English

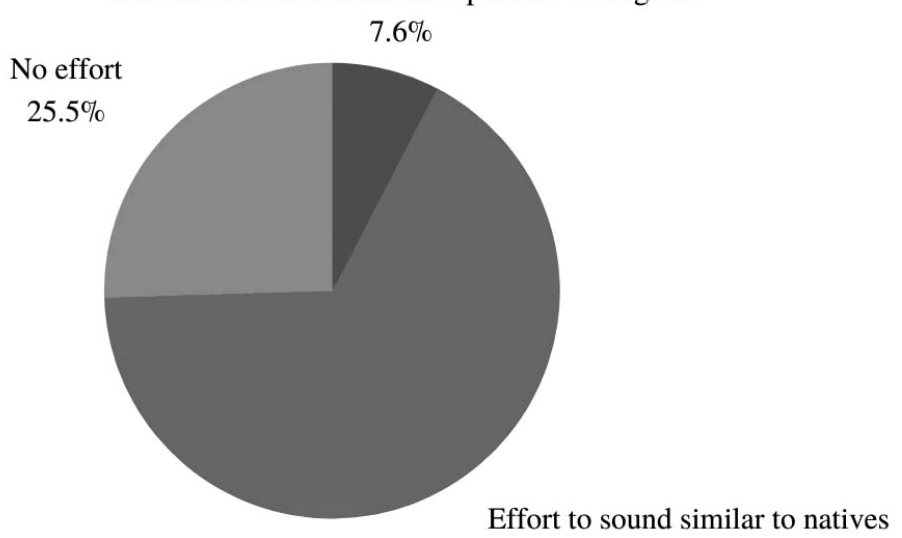

$66.9 \%$

Figure 1. Conscious decisions students make when speaking English

The next two questions explicitly signify that the Serbian portion of the students' identity networks is by no means threatened by the English language and the notions it transmits. First of all, 109 participants claim that they best convey their emotions and thoughts in Serbian. Only 30 of them choose English for that purpose, while 6 students say that, for them, there is no difference in expressing themselves in both of the languages, or that it depends on the occasion. Furthermore, 111 respondents deem Serbian culture more alluring than the English-speaking nations' cultures, whilst only 34 entertain a contrary opinion. This data negates any assertions that the spread of English poses a threat to all that is Serbian in students' identities.

The five questions to come next required students to choose between an English loanword and its Serbian counterpart. The criterion for the choice of anglicisms for this survey was that Serbian equivalents or contextual equivalents of those loanwords exist and are not archaic. For three of the five given pairs of English loanwords and their Serbian counterparts, most of the participants picked the English loanword. In the remaining two cases, the students selected the words which were in use in Serbian before the anglicism appeared. Therefore, it can be inferred that the choice between an English loanword and its Serbian equivalent depends on the specific word and not on the students' identity. Moreover, it may be said that the participants are prone to accepting English loanwords since they choose the anglicism in three out of five cases. However, more research should be conducted into this topic in order to draw a definite conclusion.

The data collected from the next question, which incorporated several Likert scales, can best be presented using a bar graph (Figure 2): 


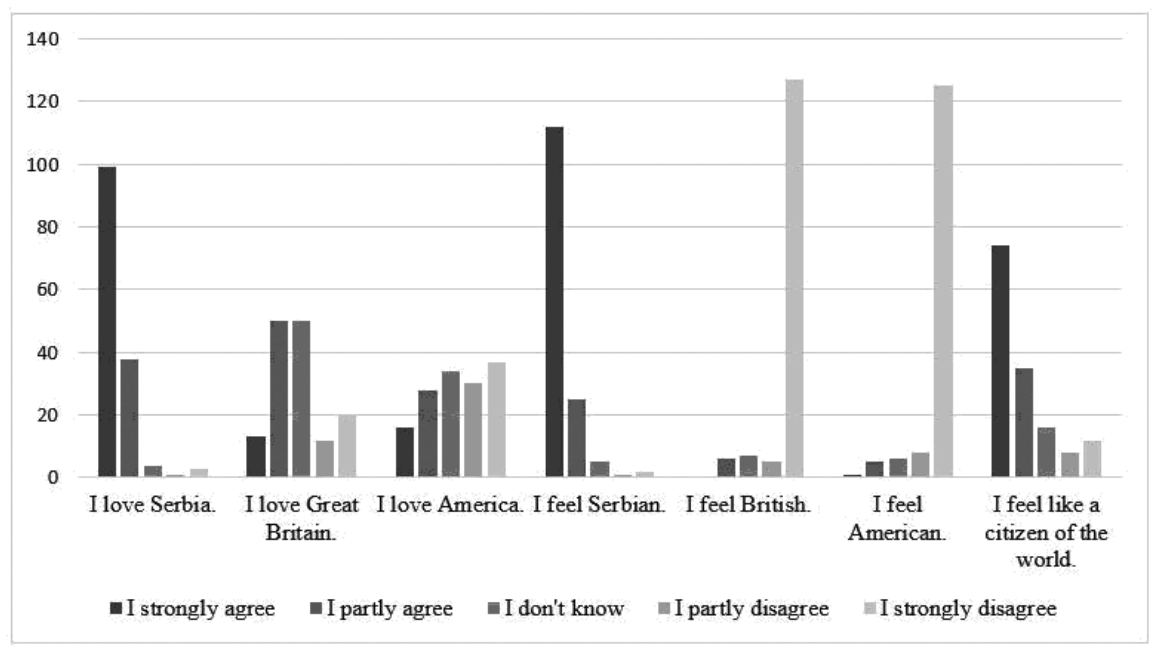

Figure 2. Likert scales (overall)

In Figure 2, the claims with which the students were supposed to express their agreement or disagreement, using the Likert scale, are positioned on the horizontal axis. The numbers on the vertical axis represent the number of respondents who gave a specific answer, while the shades denote the answers themselves - ranging from "I strongly agree" to "I strongly disagree." The results obtained by scrutinizing the data provided by this question are essential. It can be seen that an overwhelming majority of students identify with the following claims: "I love Serbia" and "I feel Serbian." Bearing that in mind, it is only expected that they adamantly oppose the statements with which they would express belonging to Anglophone national communities. The participants are divided regarding their feelings towards Great Britain and the USA, but most of them view themselves as global citizens. These results reaffirm the inference made earlier in this section that the Serbian element of the students' networks of identities has not been undermined by English in the least. On top of that, the participants are fairly certain that they feel as if they belong to an overarching global community.

The final three questions were open-ended. The first of the three questions asks whether the students ever decide to articulate diverging opinions in Serbian and English. Most of the participants (62 percent) claim that never happens to them, 9 percent of them state it occurs sometimes or rarely, while 29 percent say they express different attitudes in the two languages frequently or always. This reinforces the conclusion, drawn from many previous questions, that, on the whole, the students' Serbian identities are unshaken. In spite of that, it should be emphasized that there is a significant number of those who give English a prominent place in their identity networks, but they are most certainly not in the majority. Thus, EFL teachers should aim to strike a balance between the two disparate groups and their respective identities by employing an approach which can accommodate the needs 
of both groups. During the qualitative analysis of the answers, two important ideas arose. The first one, produced by 2 students, is that they air the same opinions in both languages, but they use English expressions and slang in their everyday Serbian speech. Also, it is easier for them to convey some notions in English than in Serbian. This places those students closer to the group with a distinguished English element in their identities. Another explanation given by the respondents is that they definitely state dissimilar attitudes in the two languages since, when they are speaking English, they are probably talking to a foreigner, who is much more liberal than their compatriots. This is also an exceedingly valuable idea since it provides us with insight into the workings of the identities of those students who strive to approach the English-speaking community as much as possible.

As for the next question, almost all respondents deem it beneficial that they are being taught English at school, whereas only one of them says the opposite, explaining that learning English is "strenuous". Not only does this question present us with the students' "yes/no" answers, but it also offers the reasoning behind such answers. Hence, the rationales behind the students' responses can be classified into three groups:

1. The global character of English - learning English is advantageous because: "everyone in the world speaks English"; "it is the most widespread language", "a universal language", "a global language"; "it removes language barriers"; "it is the language which connects us"; it enables "communication with foreigners"; it is useful "when traveling".

2. Possibilities - being proficient in English is beneficial since: "it opens up many paths in our life and career"; "it opens many doors"; "it is the basis of getting employment"; "the majority of popular movies, TV series, songs, and even art events and festivals are in English"; "it is useful"; it offers "a better future and further education"; "it can pay off the most"; it provides us with "access to a larger amount of data"; "I can find better scientific literature"; "it expands the possibilities of meeting people around the world"; "it is the basic language of the Internet and technology".

3. A necessity - proficiency in English is "necessary", "a part of general education/ culture"; "someone who does not know English is illiterate"; "it is impossible to get by in the world if you do not know English"; "knowledge of English is primary and functioning without it is unfathomable"; "everyone should/must know it"; it is "a normal thing", "the basis of everything".

4. Personal reasons - the students are fond of learning English because: "it expands us"; "it is a beautiful language"; "it is instructive to learn about other cultures, customs and languages"; "it is interesting to learn"; "for the sake of self-development"; "I love learning languages"; "it fulfills me"; "it helps me think rationally in stressful situations".

The stated directions which the respondents' reasonings took, apart from the final one, point to the fact that a substantial majority of the students see English

4 The parts of the sentences given within quotation marks are translations of the students' answers.

5 This answer was expressed partly in English and partly in Serbian and looked like this: "zarad self-development". 
as an instrument of communication, which is supposed to help them achieve their goals. Therefore, their motivation for learning English is instrumental and English is set in their identities as a vehicle of international communication. On the other hand, the last group, containing only a couple of students, has established a different relationship with English - they relate to it on a personal level and incorporate it into their networks of identities as a language they strongly identify with. Moreover, they most likely exhibit integrative motivation for learning English. The two strikingly diverging motivations (along with the diverging identities) the students display pose a considerable challenge to EFL teachers. Unfortunately, the teachers might not have risen to the challenge as well as is necessary since some of the students used this question to express their dismay with the EFL classes and curriculum. Namely, they claim that the skills and knowledge which are actually necessary are not being taught at school during their English classes. Though these might be just a few unsatisfied students, this may also be perceived as a sign that action should be taken to attune the EFL approach and curriculum in high schools to the students with instrumental motivation as well as to those with integrative motivation.

The question concluding this survey is the one eliciting the students' opinions as to which foreign languages should be taught in high schools. Approximately three quarters of the participants include English in their responses, while one quarter of them focuses on other languages. Only one participant is unsure which languages to choose. When viewed in conjunction with the results of the previous question, it can be inferred that English is the language of international communication for the greater part of the students, while other languages they list (such as Spanish, Italian, French, German, etc.) are their personal adoptive languages (terms from A Rewarding Challenge).

Bearing in mind the entirety of the analysis presented above, we can say, with certainty, that the overwhelming majority of high school students in Belgrade consider English to be an instrument of communication and a path to fulfilling their aspirations. Thus, English does not jeopardize the Serbian aspect of the students' identities in any manner. Nevertheless, there is a small but vociferous minority which relates to English on a personal level and grants it a pronounced position in their identities. This is an issue which should be addressed from the point of view of EFL methodology so that the needs of both groups are satisfied.

To end this chapter, two groups will be formed based on the students' final grades in English. The first group is made up of the students who were awarded the highest final mark, which is 5 in Serbia. The responses provided by the 89 students belonging to this group will be measured up against the overall results presented above, which will be named the frame of reference.

First, all of the participants who prefer variants other than British or American English (i.e. Australian, Canadian and New Zealand English) are higher-grade students. This implies that students who are very proficient in English have developed an increased awareness of the diverse variants of English and have even 
taken a liking to some of them. Moreover, as was presented earlier, 30 respondents in total express themselves best in English, while 6 respondents state they convey their thoughts and feelings equally well in both Serbian and English. Almost all of those respondents have the highest marks in English - 22 out of those who opt for communicating in English and all 6 of those who choose both English and Serbian. Also, as Figure 3 shows, the highest-mark students' answers to the Likert scale are quite similar to those of the entire sample. Nonetheless, it should be mentioned that the students most proficient in English are mainly those who select answers which point to a certain degree of Englishness in their identities. For instance, 3 grade 5 students say they strongly disagree with the statement "I love Serbia" (out of 3 overall), 11 of them categorically state that they love Great Britain (out of 13 on the whole), 2 students from this group strongly disagree with "I feel Serbian" (out of 2 in total) and 6 of them partly feel British (out of 6 from the whole sample). Furthermore, when the participants' explanations in the penultimate question are taken into account, it can be noted that all the answers from the "personal reasons" group are provided by the students with the best grades. The data gathered from the responses having to do with the students' preferred language of expression, the Likert scales and the penultimate question all point to the conclusion that the small but distinct group of students who incorporate English into their identities, mentioned earlier in this paper, is primarily made up of students receiving the best grades.

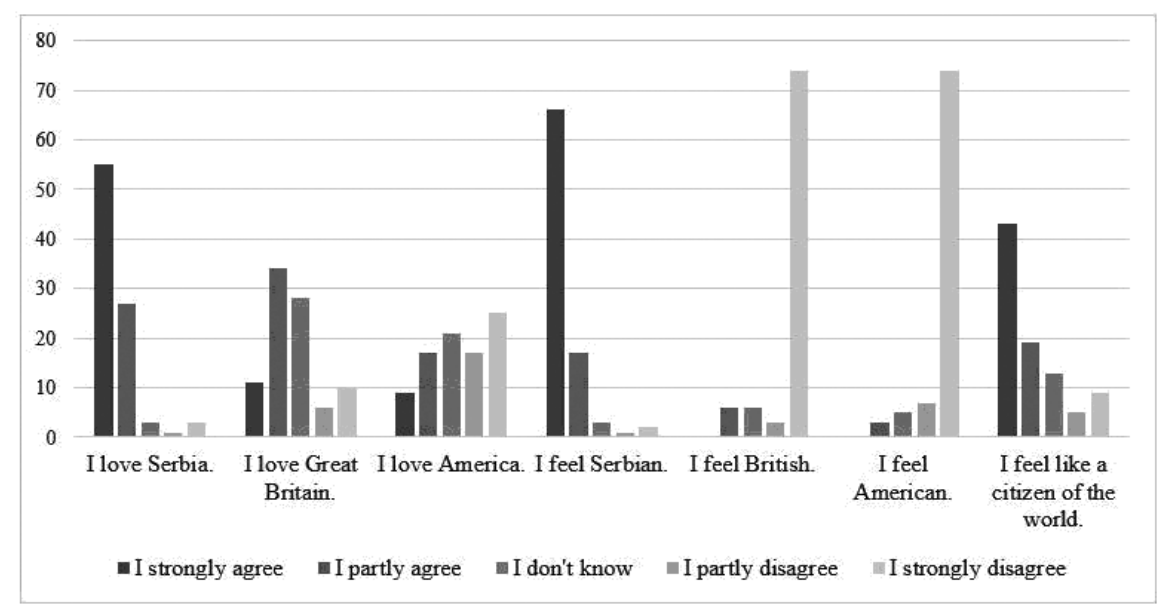

Figure 3. Likert scales (higher-grade students)

On the other hand, the 21 students who were awarded the lowest grades in English display somewhat different tendencies. Since there are no students failing English, the respondents given grades 2 and 3 were taken as the lowermark students. Firstly, the results concerning their chosen English varieties are at odds with the preferences of the complete sample. Namely, 71.4 percent of lower- 
grade students choose American English, whilst 28.6 percent of them prefer British English. Secondly, their Likert scales are strikingly different from both the sample when considered in its entirety and their classmates who received higher grades, as shown in Figure 4. For example, the students voice almost no doubt with regard to their emotions towards Serbia as an entity and their national identities. They also adamantly oppose the idea that they might identify as Britons or Americans. Lastly, the one student who holds that learning English at school is not useful at all belongs to this group. What can be inferred from these results is that the students who do not perform well in English have a stronger Serbian portion of their identities.

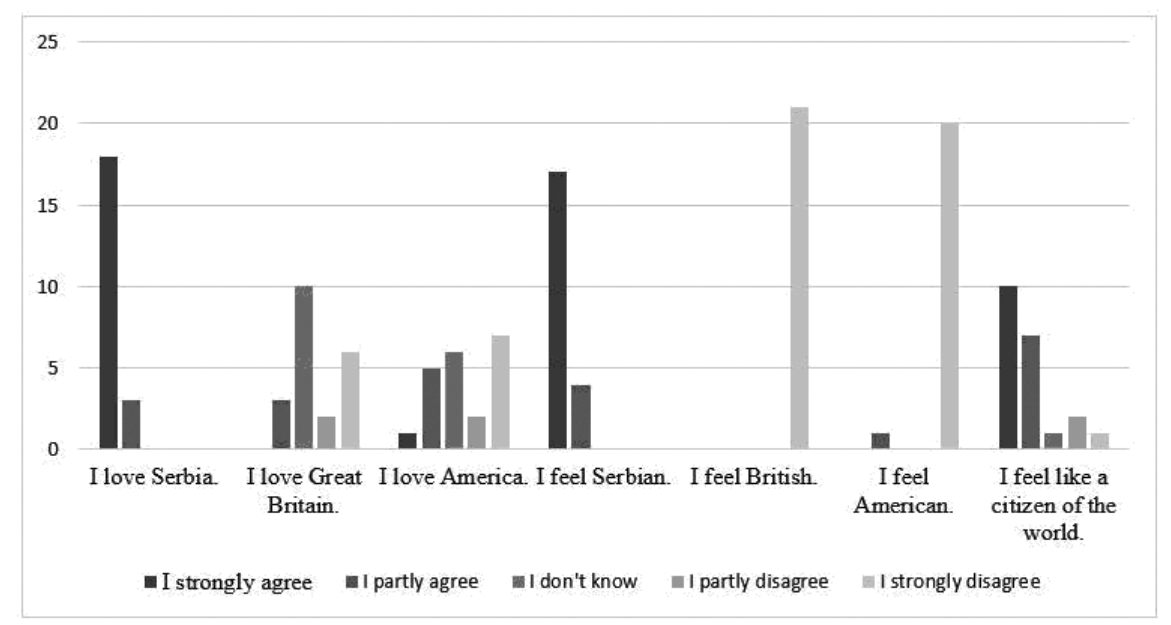

Figure 4. Likert scales (lower-grade students)

\subsection{Presentation of the interview findings}

The interviews were structured, consisting of 5 questions. The teachers' answers will be presented in this section of the paper, citing their words as much as possible.

The first teacher interviewed (T1) was from the Sixth Belgrade High School. She teaches English to three classes of fourth grade students. To begin with, she does not consider any of the English varieties to be more correct than the others, but she personally prefers the British accent since she was taught that the way people speak reflected their education and social status and that educated people used BBC English. However, she is of the opinion that, nowadays, for example, because people in Australia have their own variety and people in every region of England speak differently, the expressed claim loses its significance. Therefore, she does not expect her students to speak any particular variety of English. She accepts all varieties, especially the British and American ones. She only corrects her students when their pronunciation sounds like a Serbian version of English. Moreover, T1 thinks English has become an international language. She cites the example of her relatives living in the Netherlands and speaking English as basically a second language. Also, she 
is sure that is the case in other countries as well, where English may even have been adopted as an official language. In addition, she believes English certainly plays a role in the globalization process. Nevertheless, she states that, before all of the current events took place, she wanted the world to come together and have the same fashion and the same food, but now she sees it is not that positive. Now, she would rather that every country had its own specificities and nurtured its own culture, but that everyone knew English for the purposes of communication.

The attitudes expressed by the first teacher from the Fifth Belgrade High School (T2), who teaches two third grade classes, are slightly different. To her, language is a tool used for communication. Therefore, any form and any variety is acceptable to her if the aim - communicating with other people, exchanging ideas, acquiring knowledge - is achieved. Thus, she gives her students complete freedom, but draws their attention to the cases when the same word is used in the British and the American variety with completely different meanings (for instance, coach meaning bus in British and coach meaning trainer in American) or when there are different variants of pronunciation. She thinks that the students are mostly concentrated on American English, so it would be stifling to them if she insisted on one variant only. What is more, T2 believes that English has absolutely become an international language, bearing in mind how many words from other cultures it has adopted and made them, in a way, its own. The very facts that people are expected to be fully proficient in English in order to get any job and that groups collaborating on various projects around the world choose English as their language absolutely prove that English is dominant when it comes to communication among people. It is a strategy which has been worked on for years and now is reality. In her opinion, English has had a part in the globalization process as a means of communication. Nevertheless, economy is, to her, the only reason which can lead to globalization, though she would like the reason to be culture or art. English served as a tool for international companies and it enabled the merging of cultures and companies. To T2, globalization is a negative phenomenon since the world's wealth is in the hands of a small group of people, which goes against the values which used to be more present when each country had its own micro-economy and, with it, participated in the global economy. That leads to impersonality and grave injustice happening on a global level.

The fourth grade Fifth High School teacher (T3) was the third one with which an interview was conducted. What sets her apart from the rest of her colleagues is that she grew up in Canada. She says that, at the beginning of her career, she did not think of any of the English varieties as being the most correct one, but, having worked for eight years, she noticed that it might be best to focus on British English. She finds the British variety to be the most correct and complete one grammatically and, also, the "original" English language. In her opinion, the biggest challenge for the teachers is to make a difference between what the students see on TV and the Internet (how many faults the American and Canadian varieties have) and what is taught at school. Therefore, she expects her students to speak grammatically 
correct English according to the British variety, but she does not insist on the British accent, unless an individual student expresses a desire to speak with that accent. Furthermore, T3 claims that English has, to a great extent, remained linked to its native culture. In her view, Anglophone countries, especially England, work on maintaining their language culture and not allowing other languages to influence their language, unlike our country. Also, Anglophone countries are those who dictate language culture to other countries. Additionally, she believes the English language is the language of globalization because it is expected that people know English wherever you go and it is a language of safety for us. T3 sees both pros and cons of globalization. As for language, she holds that globalization is not a negative phenomenon since every country is successful enough in maintaining its language alive; thus, a shared global language does not pose a threat to individual languages. In spite of that, when it comes to culture, globalization is a negative phenomenon to her because the culture which spreads the most is American culture, which she deems negative. The spread of American culture, which she considers to be too liberal and, thus, not developing people's critical thinking skills, changes the gist of one people's culture and tradition and results in the loss of diversity. In terms of taking action to improve the world, in her opinion, globalization can only be positive. As regards politics, she does not think it is a good thing that countries meddle in each other's affairs, and that unique political systems should exist in each country. To conclude, the only positive aspect of globalization, in T3's view, is language since, that way, we get to know one another and get opportunities to form relationships with people from other cultures.

\subsection{Correlation between the questionnaire and the interview}

For the purposes of attempting to discover a correlation between the survey and the interview findings, the respondents were separated into groups based on which teacher they are taught by. The number of students in the groups was as follows: 54 fourth-graders from the Sixth Belgrade High School (taught by T1), 50 third-graders from the Fifth Belgrade High School (taught by T2) and 41 fourth-graders from the Fifth Belgrade High School (taught by T3). Then, according to the teachers' answers and attitudes, specific questions from the survey were analyzed in an effort to find an interrelationship between the students' answers and the teachers' opinions.

As regards T1, no noteworthy connections between her opinions and the students' answers can be established. Since the stances she maintained were relatively relaxed, the lack of a detectable teacher's influence on the students is anticipated.

With reference to T2, one link between her words and what the students had to say was discovered. Namely, T2 used the word communication several times while discussing the current relevance of English during the interview. Likewise, her students made use of the same word when explaining why they think learning English at school is beneficial for them 7 times, which is significantly more than the 2 and 3 times other teachers' students used it. Furthermore, all of those students who claim that learning English is important because of communication 
were awarded the highest final grades in English. Therefore, it can be inferred that teachers can greatly influence their students, especially the excellent ones, and the formation of their attitudes and identities.

T3 aired the strongest opinions on varieties of English and Anglophone cultures. As expected, her attitudes resounded among the students. Firstly, 41.5 percent of her students prefer British English, 46.3 percent opt for American English, while 12.2 percent choose other varieties. This is significantly different from the 59.3 percent of students who selected the American variant in the main part of the study and the 32.4 percent who picked the British variant. Moreover, the answers given by her students who received the best final grades (19 of them) deviate even more from the frame of reference -52.6 percent favor British, only 31.6 percent go for American and 15 percent like other varieties. These findings can be directly related to T3's marked preference for the British variant of English. Secondly, T3's negative emotions towards the USA can also be detected in the students' answers. For instance, more students partly and strongly disagree with "I love America" as opposed to the frame of reference (58.5 percent versus 46.2 percent). Even more discrepancies can be found between this teacher's excellent students' responses and the frame of reference. For example, 42.1 percent of them think Anglophone cultures are more attractive than the Serbian one, which is significantly more than in the frame of reference. Additionally, 21 percent of the excellent students completely agree with "I love Great Britain", which is strikingly dissimilar to the 9 percent from the frame of reference. All this data leads to one weighty conclusion - the teachers' attitudes most certainly affect the students' opinions and, along with that, their identities. Therefore, special attention should be devoted to developing the students' critical thinking skills and to teachers discussing their opinions overtly with the students so as to demystify them and control the amount of influence they exert over the students' identities.

\section{Conclusion}

To synthesize our findings, we will turn to the hypotheses stated at the very beginning and assess whether they have been confirmed or proven wrong. An overwhelming majority of students from the two Belgrade high schools have developed a kind of instrumental bilingualism, where English assumes the position of an international lingua franca, while the Serbian portion of their identity networks is untouched. However, based on the analysis of the results provided in 4., the teachers' influence on the students, especially those with higher grades, is undeniable. The teachers' attitudes are consistently reflected in the students' answers, which is why it can be concluded that the teachers' opinions play a pivotal role in shaping EFL students' identities. Thus, both hypotheses are correct and applicable to the population of Belgrade high school students.

Since the teachers' influence on the students is indubitable, we will attempt to give some recommendations on how ELT practitioners can control the impact they make on the learners. First and foremost, EFL teachers should develop the learners' 
critical thinking skills. If the students are able to discuss and critically evaluate the teacher's attitudes, their own opinions and any other stances they may come across, they will be much less likely to be influenced by any of those stances and attitudes. Furthermore, an extensive list of excellent and innovative suggestions on how to accommodate one's teaching practices to the current global position English has assumed can be found in Baumgardner (2006). For instance, Baumgardner (2006: 668) proposes that world Englishes should be introduced into the classroom by drawing the students' attention to the differences between the English they speak and other English varieties around the globe. This would be beneficial to the students on many levels, one of them being the increased awareness of the multitude of English varieties which are used worldwide (apart from British and American English), which would lead to less discrimination of the speakers of world Englishes (Friedrich, as cited in Baumgardner, 2006: 668).

The two approaches put forward here, which are two of many, lead to moving away from the native (British or American) speaker ideal which is ubiquitous in classrooms across Serbia. Moreover, what is essentially suggested here is a form of bottom-up language planning conducted by ELT practitioners. In my view, introducing necessary changes and novelties must start at the micro level, i.e. one EFL classroom, in order to be transferred to the macro level. Finally, I will reassert the importance of adjusting our teaching methods to the students' needs, types of motivation and learning styles. The moment when learning happens is when the learners' needs are center stage, while our own take a back seat.

Note: This paper is part of a longer master's thesis under the same title defended in the English Department, Faculty of Philology, University of Belgrade on June 21 2021. I would like to express profound gratitude to my mentor, Professor Ivana Trbojević-Milošević, for all the invaluable help, support and advice.

\section{References}

Bastardas-Boada, A. (2012). Language and Identity Policies in the 'Glocal' Age. Barcelona: Generalitat de Catalunya, Institut d'Estudis Autonomics.

Baumgardner, R. J. (2006). Teaching World Englishes. In B. B. Kachru, Y. Kachru \& C. L. Nelson (Eds.), The Handbook of World Englishes (pp. 661-679). Oxford: Blackwell Publishing.

Blommaert, J. (2006). Language Policy and National Identity. In T. Ricento (Ed.), An Introduction to Language Policy: Theory and Method (pp. 238-254). Oxford: Blackwell Publishing.

Bugarski, R. (2010). Jezik i identitet. Beograd: Biblioteka XX vek.

Bugarski, R. (2011). Who are you? - Profiling Individual Identities. In N. Tomović \& J. Vujić (Eds.), ELLSIIR Proceedings Volume I (pp. 11-17). Belgrade: Čigoja štampa. Coupland, N. (2007). Style: Language Variation and Identity. Cambridge: Cambridge University Press. 
Crystal, D. (2003). English as a global language. Cambridge: Cambridge University Press. Čorbić, I. (2011). Image, Reality and Standard Language. In N. Tomović and J. Vujić (Eds.), ELLSIIR Proceedings Volume I (pp. 402-414). Belgrade: Čigoja štampa.

Dyer, J. (2007). Language and Identity. In C. Llamas, L. Mullany \& P. Stockwell (Eds.), The Routledge Companion to Sociolinguistics (pp. 101-108). London: Routledge Taylor \& Francis Group.

Edwards, J. (2009). Language and Identity: An Introduction. Cambridge: Cambridge University Press.

European Commission. (2008). A Rewarding Challenge: How the Multiplicity of Languages Could Strengthen Europe. Luxembourg: Office for Official Publications of the European Communities.

Grubor, J., Hinić, D., Petrović-Desnica, J. (2011). How do EFL Teachers Feel about Touching Wood or Knocking on Wood? - Attitudes and Choice of British/American English. In N. Tomović \& J. Vujić (Eds.), ELLSIIR Proceedings Volume I (pp. 447-456). Belgrade: Čigoja štampa.

Mihaljević Djigunović, J., Cergol, K., Li, Q. (2006). Utjecaj medija na nenamjerno usvajanje engleskog vokabulara. In J. Granić (Ed.), Jezik i mediji - Jedan jezik: više svjetova (pp. 445-452). Zagreb: Hrvatsko društvo za primijenjenu lingvistiku.

Modiano, M. (2001). Linguistic imperialism, cultural integrity, and EIL. ELT Journal, 55, 339-346.

Modiano, M. (2006). Euro-Englishes. In B. B. Kachru, Y. Kachru \& C. L. Nelson (Eds.), The Handbook of World Englishes (pp. 223-239). Oxford: Blackwell Publishing.

Phillipson, R. (2000). English in the New World Order. In T. Ricento (Ed.), Ideology, Politics and Language Policies: Focus on English (pp. 87-106). Amsterdam: John Benjamins Publishing Company.

Phillipson, R. (2001). English for Globalisation or for the World's People? International Review of Education, 47(3-4), 185-200.

Tabouret-Keller, A. (1998). Language and Identity. In F. Coulmas (Ed.), The Handbook of Sociolinguistics (pp. 214-234). London: Blackwell Publishing. 


\section{Tamara Tošić}

\section{Summary}

\section{UTICAJ ENGLESKOG JEZIKA NA IDENTITET UČENICA I UČENIKA GIMNAZIJA U BEOGRADU}

Rasprostranjenost engleskog jezika na globalnom nivou dovela je do razmatranja da li engleski utiče na identitete onih koji ga uče $i$, ukoliko utiče, da li su posledice pozitivne ili negativne. Stoga, dve hipoteze koje čine srž ovog rada pretpostavljaju da je srpski element $u$ identitetima učenica $i$ učenika beogradskih gimnazija netaknut, ali i da nastavnice i nastavnici imaju centralnu ulogu u obrazovanju identiteta učenica i učenika. Podaci su prikupljeni korišćenjem dve metode - upitnika koji su popunjavali učenice $i$ učenici $i$ intervjua obavljenog sa njihovim nastavnicama engleskog jezika. $U$ istraživanju je učestvovalo 158 učenica i učenika trećeg i četvrtog razreda iz Šeste i Pete beogradske gimnazije i tri nastavnice. Analizom odgovora prikupljenih kroz dve studije potvrđene su obe hipoteze, od kojih poseban značaj ima činjenica da su nastavnice odgovorne za formiranje identiteta učenica i učenika. Međutim, podaci takođe ukazuju na to da postoji mala, ali izrazito glasna grupa učenica i učenika koja ulaže trud da se približi zajednici govornika engleskog jezika. Zbog toga, nastavnice i nastavnici engleskog jezika u Srbiji treba da rade na razvijanju kritičkog razmišljanja kod učenica i učenika, na uvođenju svetskih varijeteta engleskog jezika u nastavu, ali i na prilagođavanju pristupa nastavi kako učenicama i učenicima sa instrumentalnom motivacijom, tako i onima sa integrativnom motivacijom.

\section{Ključne reči:}

jezik $\mathrm{i}$ identitet, nastava engleskog jezika, beogradske gimnazije, svetski varijeteti engleskog jezika, instrumentalna motivacija, integrativna motivacija 